\title{
The Hungarian Education System and its School-Critical Responses
}

\author{
Ádám NAGY, László TRENCSÉNYI. Kinga HORVÁTHOVÁ•
}

\section{Abstract:}

This short description reviews the basic characteristics of the Hungarian school system and its problems. It speaks of the newly mandatory made institution of extended school and tries to outline two possible ways that are in front of the Hungarian school system.

Keywords: Education system, Hungary, extended schools

\section{The Main Characteristics of the Hungarian Education System}

Although the compulsory school age in Hungary is six, children are already obliged to attend kindergarten from the age of three. Compulsory school attendance lasts until the age of 16 (until the year of 2012 this was 18 years of age). In addition to the $8+4$ year-long primary and secondary school structure, there are $6+6$ and $4+8$ year-long structures as well.

In 2016-2017, 318000 children participated in kindergarten programmes.

The number of primary school pupils is $742000.56 \%$ of primary school pupils take part in after-school care and whole-day school programmes, in the lower level of primary school this is $87 \%$. $78 \%$ of pupils receive school meals $(92 \%$ at lower primary, $62 \%$ at upper primary). 78000 teachers work in primary schools, there is 9.6 persons per teacher.

The secondary education system was restructured in the 2016/2017 academic year. In secondary education the vocational schools (and skill-developing schools) students with special educational needs are prepared. In other schools students with SEN receive

\footnotetext{
- Adam NAGY research professor, J. von Neumann University, associate professor J. Selye University, adam@nagydr.hu

László TRENCSÉNYI professor emeritus, ELTE University, trencsenyi.laszlo@ppk.elte.hu Kinga HORVATHOVA associate professor, J. Selye University, horvathki@ujs.s
} 
integrated education.In vocational schools, students can gain professional skills during 3 years.This is followed by the so called preparation year for the school leaving exam. After four years in specialized grammar schools, students take a professional school leaving exam, and by completing one more year of study, they can obtain professional qualification linked to school leaving examination. Grammar schools are also finished with a school leaving exam.

During the Bologna process, from 2005 higher education - with the exception of some fields - was changed from united study programmes to a three-level system: the graduates of a 3-4-year bachelor's programme could apply for a 1-2-year long master's programme. The highest level was the 3-year long doctoral programme. In Hungary, during the 2016/2017 academic year, one million and seven hundred thousand children and youngsters - the $85.5 \%$ of the 3-22 year-old generation - takes part in the several different levels of daytime public education and higher education programmes (KSH, 2017).80 000 applied for daily higher education programmes, 53000 were admitted. In the 2016/2017 academic year, 206000 students took part in daily study programmes. 40000 persons received a higher education degree this year. 28\% of students - i.e. 82000 persons - in higher education continue their studies in non-daily study programmes. Out of these, 15400 received a higher education degree in 2016.

435000 persons signed up for the full time programmes of secondary school institutions. 7000 studied in vocational schools and skills development schools, 78000 studied in secondary schools, 168000 studied in specialized grammar schools and 182000 studied in grammar schools. 100000 students took part in correspondence programmes in public education institutions. 62000 passed the school leaving exam, 55\% of these graduated from grammar school and 45\% from specialized grammar school. 41000 students passed a professional exam.

\section{The typical problems of Hungarian schools}

In connection with the very strong intentions of childhood institutionalization, Mihály (1999) - one of the fathers of Hungarian school critique - describes the self-excelling process in six segments: The school forces us to understand education as the only option; it 
is a total institution strives to integrate the largest possible segment of life (in age, number, and sphere of action); primarily serves the maintenance of social order; artificially generates additional schooling needs;maintains, overproduces and generates social inequalities; and it is an impersonal institution opposing individuality and uniqueness and does not serve the development of personality. If we interpret these critics we see, that the Hungarian school system makes it difficult in three main areas: it is extremely competitive, selects too early and is very stiff (Bocsi-Nagy-Szeifer, 2017).

Hungarian schools are too competition-centred. As opposed to the often-exemplary Finnish or Estonian schools, which simultaneously teach to compete and cooperate, the Hungarian education system considers competition as a legitimate goal in its curriculum organization, assessment procedures and evaluation.

Schools - like it or not - have a kind of selective task. At the same time, in Hungary, the children's school career is in fact already narrowed down in lower primary school and is practically completely determined at secondary school. In a profane way, it could be claimed that already during the first couple of years the Hungarian school decides on who can be a worker at a petrol station and who can be a cardiovascular surgeon. One of the strongest determining factors of the attendance of secondary school institutions in Hungary is family background. The recent PISA results support the theories of inequalities in the Hungarian education system. The survey shows - in an unprecedented way in Europe - that the school and the family background in Hungary practically predetermine the learner's achievement in addition to tasks, the PISA also assesses family background). Early selection mechanisms and drop-out are linked to measures such as changing the conditions of compulsory school age or the conditions of the entry into the institutions.

Based on the research of FerencGazsó and ZsuzsaFerge(1986), it can be claimed that the curricula, student ways, methods and even physical space organization of Hungarian schools - in European and regional comparison too - are strikingly rigid ${ }^{2}$.A recent Eurofund (Eurofund, 2017) survey found that in the European Union, Hungary is the worst in social mobility. According to the study, our country offers the smallest chance for a child to find a job better than his parents. Regarding the rigidity of the school, it is not only

\footnotetext{
2 Although the research was carried out in the 1970s, it still has a good reflection on today's school system, and it even indicates how little has changed in Hungarian schools over the past half a century.
} 
necessary to renew the internal school curriculum and methodology structure, but also cooperation between the school and spaces outside the school is desirable. Especially because the European Union and the Council of Europe underline the importance and recognition of knowledge, skills and competences acquired through non-formal learning, since it improves employability.

According to Csányi (2011), "the school is an important institution from an evolutionary point of view, due to which we can thank the democratic institutions of modern states. ... without school there would be no modern society" (Csányi, 2011). But not only because it teaches to write and read, but because it "incidentally" (but according to Csányi, evolutionary by-products often become a selective advantage, i.e. hidden curriculum) teaches to rebel against the teacher, but usually also against power. According to Hungarian school critics, lifelong learning cannot be distorted as lifelong schooling, and one must not forget about the important concept of lifewide learning, which is often pushed to the background. In postmodernism, they say, the many patterns are not just an obstacle but are just a prerequisite for identity seeking and socialization (Nagy-Trencsényi, 2016). Therefore, it should not be a tolerated, permissible, suppressed phenomenon, but an indispensable element (Nagy-Trencsényi, 2012), however, in the Hungarian school only one out of the many value systems can prevail.Even though its embodying people are diverse, yet one in substance: the power factors of commitment-basedness.

\section{The extended schools in Hungary}

In Hungary, the practice of after-school care is not a new phenomenon just like the several forms of whole-day school in certain institutions. The 1993 Public Education Act understands the term as after-school care, school care and the study room as well, so it includes several different methods. Writings dealing with this issue as well as analysis describing the impacts of the operation of existing form can be found also in the literature of domestic education research (Darvas - Kende 2009, Mihály 2003). Darvas and Kende $(2009)^{3}$ highlights the impact of community development, the decrease of student

\footnotetext{
${ }^{3}$ Whole-day schools were supported as a kind of reaction due to the decline of student performances in several areas (as a kind of result of the PISA-shock).
} 
behaviour disorders, resp. that social and health services are becoming more and more accessible to children. International impact investigations report on the decline in juvenile delinquency and the decline in educational inequalities as a result of the introduction of the institution (Mayer-Varga 2017) ${ }^{4}$. The Hungarian educational institutions have faced similar problems as Western institutions: the deterioration of PISA results, the opening hours of institutions do not fit the parents' working time, the lack of targeted and developing use of leisure time, etc. In 2008, a new framework curriculum for school-based education was also introduced, hoping for a more effective and differentiated operation of the school, however, this did not bring about any substantive change; although whole-day school could play a role in equal opportunities in education (Darvas - Kende, 2009), the topic of wholeday school was not on the agenda during that time ${ }^{5}$.

From September 2013, in Hungary, in the lower level of primary school, the institution of whole-day school lasts until 4 p.m. for lower and upper-level children. From this academic year on, school care workshops, tutoring and study groups should be organized in a way so that they fit into the time frame lasting until four in the afternoon. The attendance of these workshops is obligatory, though parents can request exemption - a larger number of the parents of higher level primary school students used this opportunity. The law did not forbid teaching classes in the afternoon. Moreover, the 2011 CXC. Act on National Public Education defines whole-day schools where teaching and other classes follow each other in the morning and afternoon in proportion. Supervision must be provided by the institution until 5 p.m.

Changes in institutions have raised the cost of human resources as well as the cost of things, and the new frameworks require new material conditions. Their background is not always assured, for example, the introduction fell into a time when the source of material costs decreased, while the whole-day school increases these costs (Mayer - Varga 2017).

\footnotetext{
4 In Hungary, the staff of the Institute for Educational Research has developed research on the introduction of the full whole-day school. Their work, on one hand, points out the areas where such institutions would be most needed, they help schools organize time frames and reflect on the needs of teachers and institutions (collecting good practices, preparing educational programs to assist institutions).

${ }^{5}$ International literature generally understands the concept more widely: in many cases schools provide more complex services, connect the other institutions of settlements, resp. they connect parents more closely to the school.
} 
With regard to the new system, great advantages include the possibility of differentiation, the possibility of catching up, and the provision of recreational programs for pupils whose family and social background do not provide these. The measure is also in line with the determined hours worked by teachers i.e. 32 hours. Segregation appears to be a problem (those children stay at school who cannot pay for extra lessons elsewhere), as well as new expectations for teachers (for which they were not been prepared). Nowadays, Hungarian practice does little to promote schools to Western models, where the institution is a real community space and it provides a great number of services and focuses more on keeping in contact with the parents. In addition, the expectations that lay down the principle of flexibility and gradualism for successful establishment are not met, so that no one should feel being forced to enter whole-day schooling (Mayer - Varga, 2017). Therefore, the experiences of the period starting from the introduction are quite contradictory (Kovács - Mayer, 2015).

\section{What is next?}

Based on the above principles, it is two kinds of answers to the Hungarian school problems (Trencsényi-Nagy, 2016).

There are trends that answer with school extension. Trends that imagine reforms and a new school have provided many new functions to schools beyond the traditional "schooling of knowledge". One of the most significant changes in Hungarian public education was the introduction of whole-day schools. The measure was also justified by a number of social phenomena that are closely linked to the issue of inequalities. Looking at the PISA results, apart from the deterioration of national data, it is also clear that the differences between the institutions are very high and that the family background of children in Hungary particularly vigorously shapes students' success. Meanwhile, Hungarian society as a whole shows the signs of polarization.The concept of the day-long school thus set the goal of increasing institutional time for lower-primary pupils. The afternoon timeframes theoretically provide opportunities for complex catching-up work, talent management, and the development of skills. But institutions did not have enough time for preparation. However, the legal framework provided the possibility of exemption, respectively; the 
programmes that schools could provide would require extra resources.Researchers have also found examples of such children excluded from afternoon schools, who were the most in need of such convergence (for example, because of their behaviour or behavioural disorders, they could not stay at school in the afternoon school).The new system did not cause a serious change in the life of children since the children were in the school before that too, and in the institutions the study room and supervision had already existed. And afternoon supervision could not be provided by the parents. (Bocsi, 2015). At the same time, the lack of skilled supervision and financial resources, and the scarcity of infrastructure had an impact on implementation. Parents' opinions on all-day long school differ - the higher the parents' educational level, the more critical they are toward the change, as the law allows them to take the child from the school before 4 p.m. only upon permission (SIC!).

According to the next trend, the school's power-building structure does not give any answer to the dozens of questions that affect young people, so the trend looks for answers outside the school. Leisure environment is, in fact, different from the school, because roles are created based on spontaneously (or manipulated, but seeming spontaneous and nonpower, in Csányi's term "tyrannical") formulated communities.The Hungarian social pedagogical (with the 21st century narrative: youth) tradition - not exceeding but countering the school - offers the benefits of a wide variety of socialization patterns on the field of authorized (chosen) powerless situations outside the school. It provides a practical platform for these extra-curricular approaches ${ }^{6}$. In relation to these organizations, there is little relation to membership, the so-called postmodern forms of participation are more typical for Hungarian young people, i.e. responses typically characterize participation in a certain programme or event ${ }^{7}$.At the same time, the attacks of the Hungarian government

\footnotetext{
${ }^{6}$ About 4000 to 5,000 civilian youth organizations, representing about $8 \%$ of all Hungarian NGOs. According to data, there were 54,000 classical civil organizations (20000 foundations and 34,000 associations) in 2015 (KSH, 2016). According to the searchable database of non-governmental organizations (www.birosag.hu) we get 1500 hits for youth, another 750 for the young, 3000 hits for the child ("gyermek"), and 100 for the child ("gyerek") words. Although they cannot be summarized simply (there may be an organization with a name including the combination of these words), we can count with the approximate number of 4000-5000.

${ }^{7}$ According to the latest 2012 research data, $27 \%$ of $15-29$-year-olds have connections with a civil organization. $10 \%$ of young people have specific organizational membership, $10 \%$ of young people attended the events of an organization and 7\% participated in the activities of an organization (Fazekas-Nagy, 2015)
} 
against civil organizations and the scarcity of resources (Nagy, 2015), and administrative burdens make the existence of civil organizations difficult.

The practical impacts of the above trends are therefore very dispersed in Hungary. Although their impact could be perceived in the traditional school, eruptions were shortlived; they existed only insularly once in a while: the power of regeneration was stronger. The reason for this is the insistence of the Hungarian "school institution, the traditional inertia of the pedagogical culture and the insistence of the "guardians of the bastions» in order to preserve the attributes of their (modest) powers against the increasingly «obnoxious» student youth" (Trencsényi-Nagy, 2016, p. 83.).

\section{References}

Bocsi V. (2015): Különórák és szabadidő az általános iskolákban, In Imre Anna: Eredményesség és társadalmi beágyazottság, a délután 4-ig kiterjesztett iskola bevezetésének első tapasztalatai, Budapest: OFI

Bocsi, V., Nagy, Á.,Szeifer, Cs.: Szputnyik sokk után: uniós célokés a magyaroktatáshelyzete,Új Egyenlöség, http://ujegyenloseg.hu/szputnyiksokk-utanunios-celok-es-a-magyar-oktatas-helyzete (downloaded: 01.07. 2017)

Civil szervezetek kereshető adatbázisa, http://birosag.hu/allampolgaroknak/civilszervezetek/civil-szervezetek-nevjegyzeke-kereses

Csányi, V (2011): Társadalomés ember, Budapest: Gondolat

Darvas Á., Kende., Á (2010): Egész napos iskola - tapasztalatok és lehetőségek, Esély 3. szám, http://www.esely.org/kiadvanyok/2010_3/02darvaskende.indd.pdf

Eurofund (2017): Social mobility in the EU, research report, Publications Office of the European Union, Luxembourg,

https://www.eurofound.europa.eu/publications/report/2017/social-mobility-in-theeu, (downloaded: 17.05.2017)

Fazekas, A., Nagy, Á. (2015): Fiatalok. De civilek? - táborok ifjúságától a fesztiválok ifjúságá, Civil Szemle, 2. szám

Ferge,Zs.,Gazsó, F. (1986): A közoktatásirendszertársadalmifunkcióiésfunkciózavarai In: Szociológiaiszöveggyűjtemény. Budapest: KossuthKönyvkiadó, p. 156-176. 
Kovács., E., Mayer. J. (2015): Egész nap aziskolában? Egy fejlesztés anatómiája, Budapest: OFI, http://mek.oszk.hu/15500/15549/15549.pdf (downloaded: 01.07. 2017)

Központi Statisztikai Hivatal (2017): Statisztikai Tükör, oktatási adatok 20162017,http://www.ksh.hu/docs/hun/xftp/idoszaki/oktat/oktatas1617.pdf, (downloaded: 17.05.2017)

Központi Statisztikai Hivatal (2016): Statisztikai Tükör, A nonprofitszektor legfontosabb jellemzői 2015,

http://www.ksh.hu/docs/hun/xftp/stattukor/nonprofit/nonprofit15.pdf(downloaded :01.07. 2017)

Mayer, J., Varga., A (2017): Dilemmák az egész napo siskola nevelési-oktatási programjának bevezethetőség éről (Kritikai észrevételek), ÚjPedagógiai Szemle, 12.szám, https://folyoiratok.ofi.hu/uj-pedagogiai-szemle/dilemmak-az-egesznapos-iskola-nevelesi-oktatasi-programjanak (downloaded: 01.07. 2017)

Mihály., I. (2003): Iskolások, iskolákés a szabadidő. ÚjPedagógiaiSzemle, 4. szám, http://ofi.hu/tudastar/iskolasok-iskolak (downloaded: 01.07. 2017)

Mihály, 0 (1999): A polgári nevelés radikális alternatívái, in: Mihály, O. (szerk.): Az emberi minőség esélyei - pedagógiai tanulmányok, OkkerKiadó, Budapest Nagy, Á (2017): The taming of civil society, in Magyar Bálint-Vásárhelyi Júlia: TwentyFive Sides of a Post-Communist Mafia State,Budapest: CEU Press - NoranLibro Nagy,Á.,Trencsényi L. (2012): Szocializációs közegek a változó társadalomban - a nevelés esélyei: család, iskola, szabadidő, média. Budapest: ISZT Alapítvány

Trencsényi, L., Nagy, Á (2016): Tanórán innen, iskolán túl: a szociálpedagógiai gondolat létjogosultsága. Iskolakultúra, 10. szám 